Manachynska Yulia,

$\mathrm{PhD}$ in Economics, Associate Professor, Chernivtsi Institute of Trade and Economics of Kyiv National University of Trade and Economics Kyiv National University of Trade and Economics,

Chernivtsi, Ukraine

ORCID: 0000-0001-9155-3417

Researcher ID: S-7080-2017

Yevdoshchak Volodymyr,

$\mathrm{PhD}$ in Economics, Associate Professor,

Chernivtsi Institute of Trade and Economics of Kyiv National University of Trade and Economics Kyiv National University of Trade and Economics,

Chernivtsi, Ukraine

ORCID: 0000-0001-6547-8927

Researcher ID: Q-5888-2016

\title{
7D-MODEL OF BUSINESS DEVELOPMENT IN THE CONDITIONS OF GEOECONOMIC SCENARIOS FOR UKRAINE
}

The paper considers a new model of business development on the basis of multidimensional parameterization of modern enterprise management tasks in the context of forecast geoeconomic scenarios for Ukraine. The $7 D$ model of business management is proposed within the framework of the country's national course and 'Ukraine-2030' Balanced Development Doctrine, which combines 4D, 5D, 6D and 7D formats in its structure. The first $4 D$ format of the proposed model contains a virtual business management model with a financial plan and a system for the organization of actuarial accounting in $3 D$ and control in the selected time line $\left(t_{1}\right)$. The next $5 D$ block creates the ability to interpret accounting information from an actuarial accounting system into a 5D actuarial financial statement, which is complemented by an efficient system of controlling financial resources expenditures for the investment attraction phase. The $6 D$ unit ensures adherence to the principles of sustainable development throughout the operational and financial cycles, due to an effective system for evaluating business value in terms of wealth multiplication (value added) over the long term. 7D-format provides modeling of business development management in the complex: $6 D+$ Investment + Actuaries + Facility Management $(F M)$, which is based on the alteration of business from crisis to a stable financial state during the appropriate period of time by attracting the necessary volume of investments with the subsequent effective management of the facility management (FM). The presented model of business development is relevant for domestic economic 
entities in the context of implementation of the relevant scenario of geoeconomic shifts for Ukraine. The calculated results of the $7 D$ business development model have made it possible to interpret it in the form of hexeract and can be used to ensure the proper level of economic growth of Ukraine in accordance with the goals of balanced development within the Doctrine's framework 'Ukraine 2030'.

Key words: development, business, geoeconomics, actuary, accounting.

\section{Маначинська Юлія, Свдощак Володимир. 7D-модель розвитку бізнесу в умовах геоекономічних сценаріїв для Украӥни.}

У роботі розглянуто нову модель розвитку бізнесу на основі багатовимірної параметризачії завдань управління сучасним підприємством в контексті прогнозних геоекономічних сценарїв для України. Пропонується 7D-модель управління бізнесом в рамках державного курсу країни та Доктрини ї̈ збалансованого розвитку «Украӥна-2030», щуо поєднує у своїй структурі 4D, 5D, 6D та 7D-формати. Перший 4D-формат, запропонованої моделі, містить віртуальну модель управління бізнесом із фінансовим планом діяльності і системою організаџії актуарного бухгалтерського обліку в $3 D$ та контролю $в$ обраному часовому лазі. Наступний 5D-блок створює можливість інтерпретації облікової інформації із системи актуарного обліку в 5D-актуарну фінансову звітність, щзо доповнюється ефрективною системою контролю витрат фінансових ресурсів для етапу залучення інвестицій. 6D-блок забезпечує дотримання принщипів сталого розвитку в ході операційного та фінансових цикклів, завдяки ефективній системі очінки вартості бізнесу з точки зору примноження багатства (збільшення доданої вартості) у перспективному nеріодi. 7D-формат - передбачає моделювання управління розвитком бізнесу в комплексі: 6D+Investment+Actuaries+Facility Management (FM), щзо полягає увиведенні бізнесу з кризового до стійкого фінансового стану протягом відповідного періоду часу иляхом залучення необхідного обсягу інвестицій з подальшим ефективним управлінням інфраструктурою підприємства (FM). Представлена модель розвитку бізнесу є актуальною для вітчизняних суб'єктів господарювання у контексті реалізації відповідного сценарію геоекономічних зрушень для Украӥни. Розраховані результати 7D-моделі розвитку бізнесу дали змогу ї̈ наочно інтерпретувати у формі гексеракту (heхегасt) та можуть бути використані для забезпечення належного рівня економічного зростання Украӥни відповідно до иүілей збалансованого розвитку в рамках Доктрини «Україна 2030».

Ключові слова: розвиток, бізнес, геоекономіка, актуарій, облік.

Relevance of research topic. In the 21 st century, the seventh technological framework is formed, which is based on the development of network economy, nanotechnology and multidimensional parameterization of socio-economic phenomena and processes on a global scale. That is why, countries that do not join these processes 
are at high risk of losing their niche in the geo-economic space. On the other hand, such an accession may lead to losses from globalization and global financial crises for developed countries (Kibalnik, 2015).

Ukraine can succeed in the global economic arena by virtue of its relatively good economic location, human capital and natural resources, developing first and foremost such sectors of the national economy as: agrarian; military-industrial and information-communication technologies. These sectors are capable of delivering a $43 \%$ overall national economic growth by 2020 , and by 2030 about $53 \%$. In comparison, the aggregate contribution to the growth of low-tech and raw materials industries is estimated by experts to be within $35 \%$ by the end of 2020 , whereas it is projected to decrease to $5 \%$ by 2030 (Zhilovska, 2017). In this context, in order to realize the mechanisms of potential growth of the domestic economy within the framework of Balanced Development Doctrine 'Ukraine 2030', particular attention should be paid to the three sectors of the economy listed above. However, a detailed and comprehensive evaluation of traditional business management models indicates that they require a dramatic change in the application algorithms due to the multidimensional parameterization of the vast majority of socio-economic phenomena and processes in space and time ( $\mathrm{t}$ ). That is why, from traditional scenarios, it is necessary to select an innovative 7D-model of balanced business development, which should become an important tool for overcoming the financial situation crisis of domestic enterprises and help to attract the necessary volume of financial investments in order to realize the «optimistic» geoeconomic scenario for Ukraine.

Formulation of the problem. According to experts, in order to overcome the financial crisis, Ukraine must achieve an annual economic growth rate of more than $10 \%$. Only in such tendencies our country will be able to enter the TOP-30 of competitive countries, although forecasts for such tendencies are characterized by a rather low probability of occurrence at the level of 3\% (Zhilovska, 2017). That is why, the domestic economy and business require dramatically new models and scenarios. In particular, an algorithm for modeling and positive stabilization of business processes requires an improvement. Similarly, a modern business management system requires, in addition to financial justification, virtual modeling of business processes of the proper level of management and control in 4D-7D formats.

Moreover, the increasing interdependence of the economies of different countries, the integrity of the world economy and the deepening of the international division of labor determine the scope of globalization. The processes of globalization are quite lively at the regional level, which is conditioned by the constant active cooperation of the border areas (Grushchynska, 2015). International cooperation and deepening of cross-border cooperation is one of the important priority ways of entering the international financial markets for Ukraine in order to attract the necessary volume of capital investments in the development of domestic business. However, the accounting and information content of the traditional national model of 
business process management is not able to ensure the proper level of investment attractiveness of domestic enterprises and needs urgent improvement. Due to such circumstances, it is necessary to improve the national model of business process management in the context of optimistic geoeconomic scenario for Ukraine on the basis of innovative 7D-model of business development.

Analysis of recent researches and publications. Regarding the direct substantiation of both positive and negative geoeconomic scenarios for Ukraine, they are described in detail and comprehensively in the works of such national scientists as N. Grushchynska, O. Zhilovska, L. Kibalnik, B Markov, O. Melnychuk, O. Pelekh, O. Pyroh, V. Sidenko and others. In particular, O. Pelekh examines the structural changes in the economy of Ukraine over the last 17 years. He proves that Ukraine will gradually transform from a producer country into a consumption country and has every chance of becoming an average agricultural country in the perspective period. That is why, according to the scientist, in order to have positive structural changes in the national economy, a radical change in the directions of development in line with world tendencies is needed (Pelekh, 2018). In V. Sidenko's works special attention is paid to global structural transformations and trends of the Ukrainian economy. Thus, the scientist notes that Ukraine enters the processes of international production on the basis of a rather «asymmetric» model, which is characterized by a significant dependence on foreign markets for semi-finished products without inclusion in the international production networks on the line of imports, which is a negative trend for the future (Sidenko's, 2018). On the other hand, O. Zhilovska \& O. Melnychuk are first who propose specific timelines for launching and implementing mechanisms for balanced development of Ukraine's fundamentally new trajectory of economic growth until 2030. In particular, scientists highlight the following geoeconomic scenarios for Ukraine: 'optimistic' $(15 \%)$ - characterized by balanced development; 'Canning the crisis' (30\%), which by 2020-2030 will grow into a 'foreign entity'; Sovereign default $(30 \%)$ and collapse $(5 \%)$. According to experts, the probability of realization of fundamentally opposite scenarios is about $97 \%$ (Zhilovska, 2017). However, the development of a multidimensional 7D model of business development in the context of the implementation of an 'optimistic' geoeconomic scenario for Ukraine was not considered by scientists at all, which made it necessary to carry out research in the framework of the identified problems.

Presenting main material. Ukraine's economy is quite open, and its high sensitivity to external factors becomes a dangerous attribute from the point of view of independence. Ukrainian manufacturers are losing ground, both domestically and internationally, due to the rapid increase in demand for foreign-made goods. Wholesale and retail trades are of primary importance in the structure of the economy (Markov, 2017). Fig. 1 presents the dynamics of the geographical structure of foreign trade in domestic production over the last 22 years. 


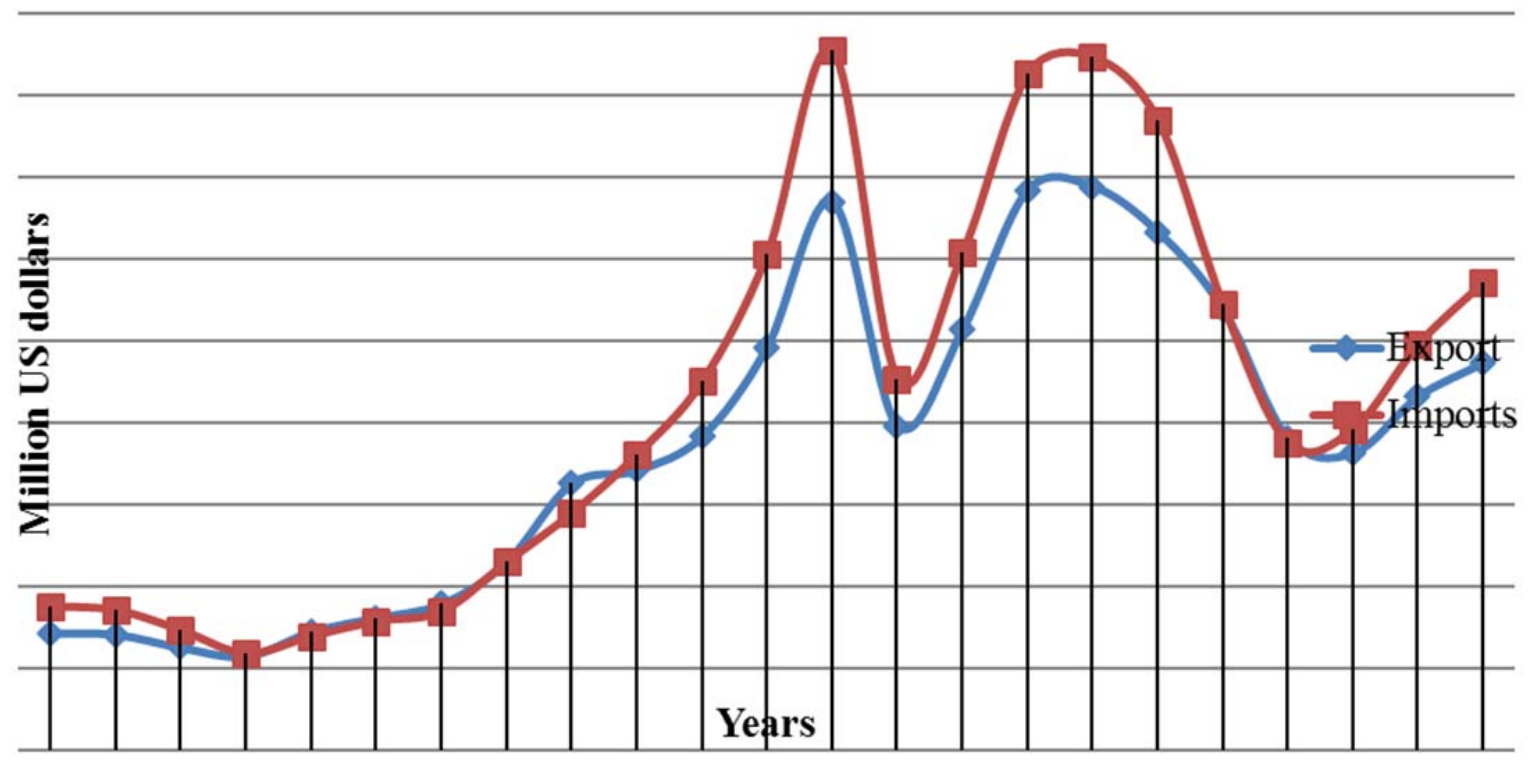

Figure 1. Dynamics of geographical activity expanding the trade goods of Ukraine for 1996-2018 (State Statistics Service of Ukraine, 2019)

It can be seen from Fig. 1 that during the studied period (1996-2018) several rather significant, both positive and negative tendencies were characterized for the foreign economic activity of Ukraine. Between 1996 and 1999, a downward trend was observed in the volume of export-import operations, but since 1999 there has been a significant increase. The peak period is 2008 - when exports reach 47335.0 million dollars. In such a case 4070.3 million dollars exceeded the 2007 figure by an absolute amount of $9.4 \%$. However, the year 2009 was characterized by a rather significant decline in export-import activity in Ukraine, when the level of exports and imports actually decreased by 2 times compared to the level of 2008. From 2009 to 2012, there was a significant revival of foreign economic activity, in particular the export level exceeded the level of 2008 and amounted to 68830.4 million dollars in 2012, the import level by 817.7 million dollars failed to reach the 2008 level and was fixed at 84717.6 million dollars. For 2012-2015, there is a significant tendency to decrease the level of export-import operations, almost to the level of 2009.

Examining structural changes in the economic development of the national economy of Ukraine, O. Pyroh emphasizes that this period (2012-2015) was characterized by a decline of the real economy at 1.3 times (Pyroh, 2017). According to the scientist, the experience of recent years shows that the main problem of the Ukrainian economy is the lack of innovative development strategy for enterprises.

The level of imports increased annually in 2015-2018, reaching the level of 2758.9 million dollars in the reporting year 2018, which exceeded the level of 2014 and amounted to 57187,6 million dollars. Moreover, exports decreased by 1,765.4 million dollars in 2016 compared to 2015, and from 2017 to 2018. This was also 
characterized by a growing trend. Furthermore, its absolute amount was 47335.0 million dollars in the reporting year 2018.

Researching the development of economy in 2000-2017, O. Pelekh notes that the structural changes in the country during the mentioned period do not contribute to strengthening stability and sustainable growth. According to the scientist, in order to ensure the necessary level of development and the required level of growth, the Association Agreement with the EU should become a strategic benchmark for structural reforms in the country (Pelekh, 2018). We agree with the scientist's opinion to some extent, but the European integration course, in our opinion, should be supported by radically different, innovative approaches to the business development management system.

There are several stages in the history of business process modeling and development. The first (1920-80's) - covered the analysis of ways of performance of works; rationalization of staff functions; paper models; it was characterized by a rather low level of automation. The second one (1990s) was based on manual reengineering while creating the model; this stage was characterized by CIS (computer information systems) automation with workflow support (WfMS, ERP). The third (from 2000 to the present) - is characterized by business process management (BMR); continuity of change; flexibility; adaptability; interactive improvement (Development of business, 2017).

Multidimensional modeling technology (in 3D, 4D ... 9D formats) is used in almost all spheres of public life. It is most actively implemented in Building Modeling (BIM) (Trach, 2017), but this approach is not used at all to build an effective business development management model for any sector of Ukraine, so we propose a 7D business management model in within the framework of the country's national course and the Balanced Development Doctrine 'Ukraine-2030', which combines 4D, 5D, 6D and 7D formats in its structure. The proposed 7D model has the form of hexeract, which is a prototype of the cube in $6 \mathrm{D}$ format. In our opinion, its practical implementation will ensure the implementation of an 'optimistic scenario' for Ukraine, the probability of which is $15 \%$, and will help to provide 'balanced development' of business in our country, which experts estimate at 3\%, Fig. 2.

The first component of the proposed 7D model of business development management under the conditions of geo-economic scenarios for Ukraine is the 4D block. It includes a virtual business development model for an individual enterprise, which includes: a financial plan of activity; the system of the organization of actuarial accounting in 3D and control in the selected time t.

Actuarial accounting derives its name from the term «actuary» (from Latin. Actuaries - accountant; cursive). 


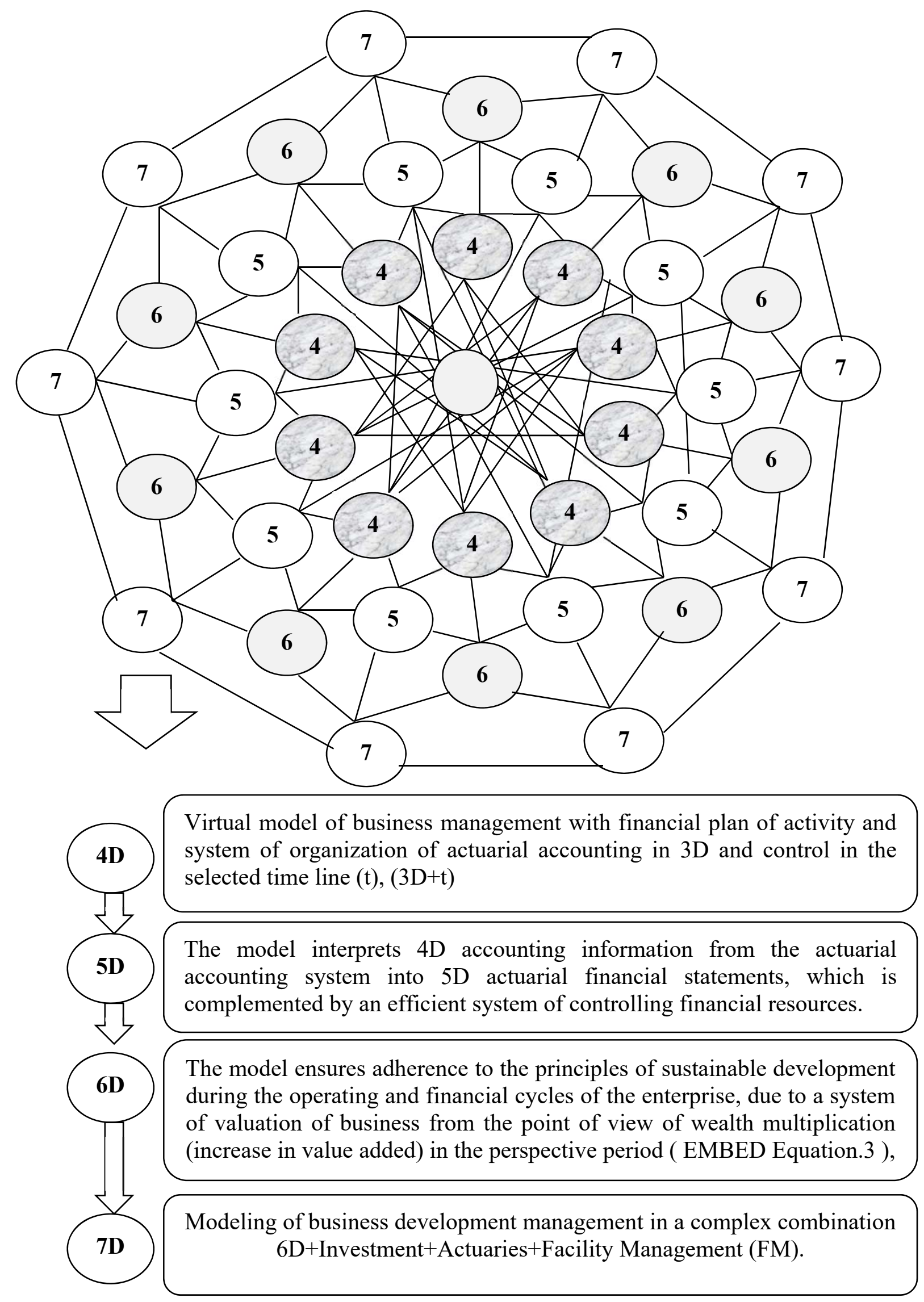

Figure 2.7D model (Hexeract) of business development in Ukraine [author's own method] 
In the 21 st century, the actuary is a certified specialist in financial risk assessment and a specialist in the practical application of actuarial mathematics.

The next 5D unit transforms 4D actuarial accounting information into 5D actuarial financial statements, enabling real and potential investors to have the necessary business investments for the future prospects.

In the $6 \mathrm{D}$ block, the $5 \mathrm{D}$ format described above is complemented by an effective business value measurement system based on 5D actuarial reporting data, the algorithm of which is substantially optimized through the prism of actuarial accounting.

7D format - provides modeling of business development management in a complex combination of $6 \mathrm{D}+$ Investment + Actuaries + Facility Management (FM), which is based on the alteration of business from crisis to a stable financial state during the appropriate period of time by attracting the necessary volume of investments with the subsequent effective management of the infrastructure of the enterprise facility management (FM) and with the involvement of certified actuarial staff. Infrastructure Management (FM) - involves the integration of the individual processes of an enterprise that services and develops an individual service, contributing comprehensively to improving the ultimate level of efficiency of an entity remotely.

According to official data of the site monetary-flow ('Custom Business Plan') created by the company «Intellect-Nova», among the TOP-22 promising ideas for business in 2019 , the $20^{\text {th }}$ position has a remote control of employees - as a promising business of the future (Polenchuk, 2019). That is why facility management (FM), as an important component of the proposed 7D business development management model, should justify the expectations of the rational use of the financial investments involved.

Expert estimates indicate that the most important factors in Ukraine's current investment attractiveness include: low levels of corruption (79.8\%); transparent and clearly defined legislative and regulatory framework (70.2\%); political stability (69.2\%). Among the three main conditions that influence the company's decision to increase the volume of investments in Ukraine are: favorable business environment (62.8\%); macroeconomic stability $(60.6 \%)$; political risks $(50.0 \%)$. The five most important conditions to be implemented to improve the overall business and investment climate in Ukraine are: reduction of corruption and bureaucracy (93.6\%); establishing the rule of law by implementing judicial reform and amending procedural law (70.2\%); guarantee of security of property rights (58.5\%); ensuring proper law and order $(55.3 \%)$; repatriation of unlimited dividends by foreign investors $(42.6 \%)$ (Ukrainian economy review, 2018).

Conclusion. The proposed 7D business development model is relevant for domestic entities in the context of implementing the relevant geoeconomic shift 
scenario for Ukraine within the Doctrine 'Ukraine 2030'. The calculated results of the 7D business development model made it possible to interpret it in the form of hexeract and can be used to ensure the proper level of economic growth of Ukraine in accordance with the goals of balanced development within the implementation of the 'optimistic' geoeconomic scenario.The 7D model of business development meets the basic principles for building information models of business entities management, which are distinguished by R. Trach, namely: 1) is an agreed database of graphical and descriptive actuarial accounting information, a database of promising data on changes in the economic value of business ; information from the 7D model can be obtained as needed; 2) is based on a single information model of business development according to the chosen strategy of production management and process of sale of products (goods); 3) support is provided for distributed groups: staff, investors, owners, shareholders, methods and tasks can effectively use this actuarial accounting information, which eliminates errors in their transfer and conversion; 4) universalisation of data exchange formats between software complexes for various purposes (Trach, 2017).Practical implementation of the 7D model at domestic enterprises, regardless of the economic sector, will help to increase the level of investment attractiveness of business. The country's investment attractiveness includes: the size of the market and its attractiveness; education and human capital; research and innovation; infrastructure; the administrative and regulatory environment; financial sphere; taxes and expenses; quality of life; focus on the 'green future' (Zhilovska, 2017). The proposed 7D-model is an innovative approach to the system of modeling business development in spatial dimension, and its active practical implementation by domestic enterprises will enable the implementation of positive scenarios of balanced development of Ukraine until 2030, which serves as a prospect for further exploration within the outlined issues.

\section{REFERENCES}

1. Grushchynska N. Geoeconomic processes of southeast asian nations in modern conditions. Scientific Bulletin of the International Humanities University. Series: Economics and Management. 2015. Vol.10. P. 32-35.

2. Development of business process modeling. (2017). ELMA. Business Process Management. Retrieved from https://life-prog.ru [in Russian].

3. Zhilovska, O.I., \& Melnychuk O.A. Ukraine 2030: The Doctrine of balanced development. Lviv, Calvary, 2017. 164 p.

4. Kibalnik L. Main directions of geo-economic transformations in the conditions of world financial crises. Actual problems of international relations. 2015. Vol. 115. Is. 2. P. 49-56. 
5. Markov B. Structural changes in the system of economic phenomena and processes. Black sea economic studies, 2017. Vol. 22. P. 45-50.

6. Pelekh O. Structural shifts in the economy of Ukraine (2000 - 2017). Scientific Bulletin of Uzhgorod National University. 2018. Vol. 21. Is. 2. P. 61-67.

7. Polenchuk, V.V. (2019). Idei dlia biznesu 2019 roku. Top-22 najtsikavishykh idej [Ideas for business 2019. Top 22 most interesting ideas]. Hroshovyj potik Monetary Flow, 1(01), 57-65. Retrieved fromhttp://monetary-flow.com/ [in Ukrainian].

8. Pyroh O. Structural changes in the economic development of the national economy of Ukraine: branch section. Young Scientist. 2017. Vol.4 Is. 44. P. 729-735.

9. Sidenko V. Global structural transformations and trends in Ukraine's economy. Economics and Forecasting. 2018. Vol.1. P. 1-30.

10. State Statistics Service of Ukraine. (2019). The official website. Retrieved from http://www.ukrstat.gov.ua/ [in Ukrainian].

11. Trach R. Building Information Modeling (BIM): Essence, Stages of Formation and Prospects for Development. Economics and Enterprise Management. 2017. Is. 16. P. 490-495.

12. Ukrainian economy review. (2018). Horizon Park Business Center. American Chamber of Commerce. Retrieved from http://www.chamber.ua [in Ukrainian]. 